\title{
DAMPAK MONOPOLI GARAM DI MADURA PADA ABAD XX
}

\author{
Oleh: Drs. Parwoto, M. Hum dan Drs. Mudji Hartono, M. Hum ${ }^{1}$
}

\begin{abstract}
Abstrak
Madura sering disebut sebagai pulau garam. Pembuatan garam di Madura merupakan mata pencaharian pokok sebagian penduduk madura, terutama di daerah sepanjang pantai selatan, yangmasuk wilayah kabupaten Sampang dibagian barat, Pamekasan dibagian tengah,dan Sumenep di bagian timur pulau madura. Pada awal abad ke-20 pemerintah Hindia Belanda menerapkan praktek monopoli garam di Madura sudah tentu monopoli itu berpengaruh terhadap kehidupan penduduk pembuat garam, tulisan ini bertujuan untuk membahas sejauh mana dampak monopoli garam itu di Madura?

Hasil kajian menunjukkan bahwa monopoli garam di Madura yang berlangsung pada abad ke-20 dilakukan oleh dinas regie dengan modalperusahaan atau pabrik. Monopoli garam itu dipandang oleh pemerintah Hindia Belanda sebagai bagian dari sistem pajak, sebaliknya oleh penduduk dipandang sebagai bentuk eksploitasi yang merugikan, oleh karena itu mengakibatkn munculnya berbagai bentuk perlawanan rakyat terhadap monopoli itu. Bentuk perlawanan itu antara lain: pembakaran gudanggudang garam oleh penduduk; pelanggaran peraturan monopoli dengan sengaja, seperti petani garam tidak bersedia menyerahkan garamnya kepada pemerintah; banyak orang bermigrasi ke daerah ujung timur Jawa Timur untuk mencari nafkah selama musim garam; pembuat garam melakukan mogok kerja; dan penduduk mengadakan pertemuan-pertemuan dan menuntun kenaikan harga garam dan upah buruh. Meskipun perlawanan rakyat Madura terhadap monopoli itu dikordinasi oleh SI, dan pemerintah Belanda tidak merespon dengan kekerasan, tetapi perlawanan itu tidak membuahkan hasil, maka hal ini dapat diartikan sebagai kemrosotan SI lokal Madura.
\end{abstract}

Kata kunci: monopoli, garam, Madura.

\section{A. Pendahuluan}

Madura sering disebut sebagai pulau garam, Karena banyak orang di pulau itu pekerjaanya membuat garam, selain itu banyak tempat yang digunakan untuk membuat garam, dengan demikian selain hasil produksi garam setiap tahunnya berjumlah banyak, pembuatan garam merupakan mata pencarian pokok sebagian penduduk Madura, serta garam yang dihasilkan memiliki kualitas baik.

\footnotetext{
${ }^{1}$ Drs. Parwoto, M. Hum adalah staf pengajar Jurusan Sejarah di Fakultas Sastra, Universitas Negeri Jember. Drs. Mudji Hartono, M. Hum adalah staf pengajar Prodi Ilmu Sejarah di Fakultas Ilmu Sosial, Universitas Negeri Yogyakarta.
} 
Daerah tempat pembuatan garam berada di sepanjang pantai selatan, yaitu kabupaten Sampang di bagian barat pulau, Pamekasan di bagian tengah dan Sumenep di bagian paling timur. Daerah itu disebut sebagai daerah garam, yang pada jaman VOC dikenal dengan zoutnegorizen, dan pada jaman Hindia Belanda zoutlanden. Di sepanjang daerah garam itu terdapat 4.572 empang garam; di Sampang ada 1.377 empang, di Pamekasan 1.547 empang, dan di Sumenep 1.648 empang garam. Sejak tahun 1882 pemerintah Belanda menerapkan politik monopoli garam di Madura, baik dalam hal pembuatan dan jumlah produksinya maupun tentang penjualanya dikuasai ole pemerintah Belanda. Bagi pemerintah, garam mempunyai nilai ekonomi yang tinggi, sejak tahun 1915 pemerintah membentuk dinas regie.

Dalam prektek monopoli garam dapat dilihat pada pengelolaanya, sejak pengelolaan garam ditangani dinas regie, maka menggunakan cara pabrikan, dan hasil produksinya disebut garam briket, yaitu garam pasir yang dicetak dalam bentuk kubus dengan ukuran tertentu antara lain $1 \mathrm{~kg}, 5 \mathrm{~kg}, 10 \mathrm{~kg}, 15 \mathrm{~kg}$, dan $25 \mathrm{~kg}$. Ternyata pengelolaan garam oleh dinas regie belum menunjukkan peningkatan yang baik.

\section{B. Madura Sebagai Pulau Garam}

Madura sering disebut sebagai pulau garam sebab di pulau seluas $5.304 \mathrm{~km}^{2}{ }^{2}$ itu terdapat banyak tempat yang digunakan untuk membuat garam, selain itu juga banyak orang yang bermata pencaharian sebagai petani garam.

Adapun pembuatan garam itu terdapat di sepanjang pantai selatan baik dikabupaten Sampang, Pamekasan, ataupun Sumenep. Disepanjang pantai selatan terdapat 4.572 buah empang garam dan ditempat-tempat itu didirikan gudang-gudang garam yang namanya sesuai nama desanya. Di Sampang gudang-gudang garam berada di daerah Pragung, Dangpandang, Pangarengan, dan Apaan. Di Pamekasan gudang garam ada di Mangunan, dan Capak; di Sumenep ada di Marengan, Palebunan, Pinggir Papas, dan Sarokan.

Daerah pembuatan garam di pantai selatan itu di dukung oleh faktor alam. Sehingga hasil produksi garam memiliki kualitas yang baik. Pertama, air laut di pantai selatan mengandung kadar garam yang sangat tinggi. Kedua, daerah pantai selatan dilalui oleh angin gending.$^{3}$ Oleh karena itu pengkristalan garam berlangsung sangat cepat. ${ }^{4}$

\section{Pelaksanaan Monopolio Garam}

Kata monopoli berasal dari kata Yunani ; monopoolion yang berarti satu penjualan.

\footnotetext{
${ }^{2}$ Huub de Jonge. Madura Dalam Empat zaman, Pedagang, Perkembangan Ekonomi dan Islam ( Jakarta: Gramedia 1989), hlm. 5.

${ }^{3}$ Angin Gending ialah angin yang bertiup dari gunung semeru dan gunung tengger ke daerah pantai selatan Madura melewati Purbolinggo.

${ }^{4}$ W. Van Braam menyatakan bahwa " kenyataan bahwa kesempatan membuat garam di pantai itu lebih baik dari pada daerah yang lebih ke barat karena musim kemaraunya makin ke timur makin karakteristik", dalam Koloniale Studien: 1916/1917, hlm. 83-84.
} 
Menurut Robinson dalam monopoli itu terdapat pemegang kekuasaan tunggal mengenai pengawasan produksi itu. ${ }^{5}$ Dengan sendirinya hal ini sudah termasuk dalam segi persediaan dan sekaligus pemasarannya. Berhubung penjualnya hanya satu maka penawaranya tidak akan terjadi persaingan, maka pemegang monopoli dapat menentuka harga serta jumlah produksi dengan bebas. ${ }^{6}$

Kenyataanya pemegang monopoli dalam hubungannya dengan monopoli garam tidak dapat bebas secara mutlak dalam menentukan harga dan jumlah produksi. Hal itu di sebabkan garam hanya di produksi selama musim kemarau. Bahkan pada saat memproduksi garam berlangsung, tetapi tiba-tiba turun hujan, maka produksi garam itu akan gagal. Jadi faktor iklim berpengaruh terhadap kegiatan pembuatan garam.

Monopoli mempunyai arti adanya 1 penjualan dari satu barang atau jasa dalam suatu pasar. sehubungan dengan monopoli garam ini, yang dimaksud pemegang tunggal dalam penjualanya adalah pemerintah kolonial melalui birokrasi yang talah di tentukan. oleh karena itu pemerintah mewajibkan semua ladang garam di madura untuk digunakan membuat garam. Dalam pelaksanaanya, pemeritah membuat suatu rencana tertentu yakni setelah kolam-kolam garam itu siap untuk membuat garam maka semua pemilik kolam itu dipanggil oleh kepala pembuatan garam ke kantor daerah garam setempat dengan disaksikan oleh kepala desa dan kepala distrik, pemilik kolam dipanggil satu persatu untuk di tanyai untuk melaporkan siapa yang akan membuat garam di kolamnya. Sementara itu semua kolam yang digunakan untuk pembuatan garam dicatat dalam selembar kartu yang di susun secara teratur. Kartu itu memuat semua data yang berhubungan dengan kolam, seperti produksi garam yang dihasilkan dalam beberapa tahun sebelumnya, pemiliknya, pembuyayaan, dan bahkan sebab-sebab berpindah tangan bila hal tersebut terjadi. Pemanggilan para pemilik kolam garam oleh kepala pembuatan garam itu biasa disebut penaksiran. ${ }^{7}$ Permulaan pembuatan garam biasanya dilakukan pada akhir bulan april sampai dengan awal mei. Apabila telah ada ketentuan pembuat garam dari masing-masing kolam itu. tidak terkecuali apakah pemiliknya ataupun orang lain yang telah ditentukan. Maka pembuat garam itu segera mengambil surat ijinya di kantor pada waktu yang telah di tentukan. Surat itu merupakan bukti secara resmi bahwa yang bersangkutan adalah yang berhak sebagai pembuat garam dalam kolam tersebut. Surat itu selain memuat aturanaturan yang harus dilaksanakan juga memuat rekening koran dari pembuatnya. Surat ijin pembuatan garam tersebut disebut pepel yang ditulis dengan memakai bahasa Belanda dan bahasa Madura. ${ }^{8}$

Monopoli garam itu terwujud karena adanya perlindungan dari UU, ketentuan yang

\footnotetext{
${ }^{5}$ Pendapat Robinson ini dikutip oleh Edward Hastings Cham Berlin, The Theory of Monopolitic Competition (London : Oxford University Press, 1956), hlm. 209.

${ }^{6}$ Ensiklopedi Nasional Indonesia, (Jakarta:P.T Cipta Adi Pustaka, 1990). hlm. 363.

${ }^{7}$ W Van Braam, dalam Koloniale Studien 1916-1917(1917). hlm. 91-92.

${ }^{8}$ Ibid., hlm. 92.
} 
menyangkut adanya larangan pembuatan garam, kecuali untuk daerah yang di sebut seperti Jawa dan Madura, pantai Barat Sumatra dan seterusnya termuat dalam Staatblad Van Nelerlandsich Indie nomor 73 tahun 1882 ayat 1. Dibalik adanya larangan itu, terdapat juga aturan yang mewajibkan pembuatan garam bagi para pemilik kolam garam yang berada di daerah monopoli. ${ }^{9}$

Belanda menerapkan politik monopoli itu sebenarnya telah dilakukan sejak zaman VOC. Beberap kontrak yang dilakukan dengan berbagai penguasa lokal seperti dengan Palembang pada tahun 1662 dan 1678, memiliki maksud untuk menjamin monopoli. Demikian pula dengan adanya hubungan dengan penguasa mataram pada tahun 1677 VOC memperoleh hak monopoli untuk menjual kain dan candu dipelabuhan-pelabuhan Mataram. ${ }^{10}$ Kebijaksanaan monopoli garam dilaksanakan oleh pemerintah, dengan pertimbangan bahwa hasil produksi itu merupakan sumber pendapatan yang penting untuk pemerintah. Keuntungan yang diperoleh itu bukan digunakan untuk pemerintah di pulau madura melainkan untuk pemerintah kolonial. Keuntungan bersih dalam setiap tahunnya sejak 1916-1920 rata-rata lebih 9 juta golden. Keuntungan itu digambarkan dalam tabel berikut.

Tabel

Keuntungan Bersih dari Monopoli garam di Madura tahun 1916-1920.

\begin{tabular}{|l|l|l|}
\hline & Tahun & Jumlah Keuntungan \\
\hline 1916 & 9.220 .205 .09 \\
1917 & 9.958 .217 .69 \\
1918 & 10.274 .753 .37 \\
1919 & 10.083 .605 .29 \\
1920 & 9.304 .698 .00 \\
\hline
\end{tabular}

Sumber : Kuntowijoyo,1980,OP.cit,h. 188. Robert Cribb, The late Colonial State in Indonesia, Politikal and Economic Foundation of the netherlands Indies 1880-1942(Leiden : KITLV Press 1994), hlm. 196.

Pemerintah belanda memandang monopoli garam sebagai bagian dari pelayanan kerja; semacam cultuur diensten yang berlangsung di Jawa. Setelah pelayanan kerja dan pelayanan menanam di hapuskan maka monopoli di pandang sebagai bagian dari sistem pajak. ${ }^{11}$

Mengenai pengelolaan monopoli itu sendiri sudah terjadi jauh pada masa lampau sejak masa VOC raja-raja di Madura memiliki cara tersendiri dalam mengeksploatasi garam di Madura. Penjualan garam itu digadaikan kepada orang Cina. Dalam setiap tahunnya raja madura memperoleh 2000 gulden. Adanya pembelian gadai itu maka garam madura hanya dibeli dengan harga f 5 - f 6 untuk setiap koyang. ${ }^{12}$

\footnotetext{
${ }^{9}$ Ordonansi ini tercantu dalam Staatblad van N.I yang dikutip oleh P.H. Van Der Kemp, Op. Cit., hlm. 13.

${ }^{10}$ Schieke, Indonesia Sociological Studies (Bandung:Sumur Bandung.1960), hlm. 62-78.

${ }^{11}$ Kuntowijoyo , 1980, hlm. 382.

${ }^{12}$ Ibid., h. 534. Lihat juga Van der Kemp, Op. Cit., hlm. 264. 1 koyang = 30 pikul atau $1825 \mathrm{~kg}$.
} 
Monopoli garam di laksanakan pada tahun 1882. berdasarkan undang-undang yang di buat oleh Hindia Belanda atas nama raja dan dilaksanakan oleh dinas zoutregie. Sejak zaman VOC raja-raja di madura mempunyai cara mengexploatasi garam yaitu penjualan garam dengan cara menggadaikan kepada orang Cina. Dalam setiap tahunya raja Madura memperoleh sekitar f 2.000 .

Dengan cara itu maka garam Madura hanya dibeli dengan harga f 5 - f 6 per koyang. sudah termasuk biyaya transportasi pembuatan hingga ke pantai tempat perahu-perahu garam bersandar guna mengangkut garam guna ke tempat tujuan, Jawa. Parapembeli gadai memperoleh keuntungan selain dari export garam juga dari pajak atau pungutan sebagai pajak dari penduduk daerah garam. Seperti pajak tegalan dan pekarangan, pajak perikanan, pajak kepala DSB. ${ }^{13}$

Pada masa pendudukan inggris, rafles menghapus sistem gadai itu kemudian ia mengambil alih pengelolaan garam dari orang-orang Cina. Dengan adanya persetujuan dari raja-raja Madura, Rafles memberikan ganti rugi sebesar f5000 pertahun dan garam 50 koyang. Garam sebanyak itu dimaksudkan untuk keperluan raja sedangkan uang itu digunakan untuk para pembuat garam. Dalam pembuatan garam Rafles mengangkat superintendan sebagai kepala dinas pengelolaan garam di Jawa dan Madura. Daerah jawa dan madura dibagi menjadi 3 bagian yang masing-masing bagian di kepalai oleh seorang agen. Masing-masing bagian itu masih dibagi menjadi beberapa tempat dan seluruh tempat dalam bagian itu dikelola oleh agen.

Setelah rafles meninggal pengelola garam di lanjutkan oleh pemerintah Hindia Belanda. Hampir selama 1 abad pengelolaan garam hampir tidak jelas. Pengellaan secara sentralisasi yang dipegang oleh departemen Van Onder wijs Eeredienst en Nijverheid dan sentralisasi dibawah kekuasaan residen selalu berubah-ubah. pergantian kedua sistem itu disebabkan adanya krisis garam. Lahirnya Undang-undang monopoli pada tahun 1882 belom dapat memperbaiki pengelolaan garam.

Pada tahun 1909 muncul pemikiran untuk membentuk 1 badan yang hendak mengelola garam berhubungan dengan zoutregie itu. Usaha ini terlaksana pada tahun 1915 dengan diterapkanya dinas regie secara definitih. ${ }^{14}$

Dengan terbentuknya zoutregie maka berarti pengelolaan garam dipegang oleh pemerintah dan organisasinya ditata secara administratif perusahaan dalam pelaksanaan dibantu dengan tata buku yang tersusun baik. Dan dengan struktur organisasi sebagai berikut.

\footnotetext{
${ }^{13}$ P.H. Van Der Kamp, hlm. 265.

${ }^{14}$ Van Braam “De Zoutregie, dalam Koloniale Studyen(1917), h. 16.
} 


\section{STRUKTUR ORGANISASI \\ DINAS ZOUTREGIE}

Kepala Dinas

Kepala

Pembuatan Garam Madura

Beheerder (Sampang)

Wakil Beheerder

Pengawas

Mantri

Mandor

Pembuat Garam
Beheerder (Pamekasan)

(Sumenep)

Wakil Beheerder

Beheerder

Pengawas

Mantri

Mandor

Pembuat Garam
Beheerder

Wakil

Pengawas

Mantri

Mandor

Pembuat Garam

Dinas Zoutregie itu dipimpin seorang kepaladinas dan dibawah naungan departemen Governementsbedriven. Kepala dinas itu membawai kepala pembuatan garam di berbagai daerah pembuatan garam.

Mengenai personalia pembuatan garam di Madura tahun 1916 adalah sebagai berikut: 1 orang pembuatan garam (hoof van den aanmaak), 3 orang pengatur/pelaksana administrasi (beheerders), 3 orang wakil pengatur ( hulpbeheerders), 14 orang pengawas (opzichters), 3 orang mantri kepala(hoofd mantris), 24 mantri, 44 mandor tetap, 4 penulis (schrijvers), 3 agen polisi kelas satu, 18 polisi kelas dua. ${ }^{15}$

Selama 5 tahun dari 1916-1920 organisasi pengelolaan garam di Madura tidak ada perubahan yang berarti. Perubahan yang terjadi sifatnya hanya sementara dan berupa penambahan dan pengurangan personil yang ada dalam bagian paling bawah dalam setruktur

\footnotetext{
${ }^{15}$ Verslag Van Den Zoutaanmak Op Madura, Over het Jaar 1916, hlm. 4.
} 
organisasi seperti pada jabatan mantri, pengawas, mandor, penulis.

Mengenai pengelolaan garam secara perusahaan diawali dengan didirikanya pabrik garam briket, yaitu pabrik garam di kali anget didirikan pada 1899, pabrik garam yang kedua di dirikan di Mangunan, di wilayah pamekasan dan pabrik gula ketiga didirikan di Krampon wilayah Sampang(1903).

Mengenai pabrik garam mangunan tak pernah di pakai untuk membuat garam karena secara ekonomis tidak menguntungkan sehingga di pindah ke Bander. ${ }^{16}$

\section{Dampak Monopoli Garam di Madura}

Pemerintah Belanda telah memandang monopoli garam sebagai bagian dari pelayanan kerja semacam pelayanan penanaman, cultuul Diensten yang ada di Jawa. Ketika pelayanan penanaman dihapuskan maka monopoli ditempatkan sebagai bagian dari sistem pajak. Oleh karena itu rakyat yang bersangkutan mempunyai kewajiban untuk melaksanakan tugas itu pada negara demi kepentingan hukum.

Perkembangan produksi garam dipengaruhi oleh faktor iklim dan kebijakan pemerintah sebagai pemegang monopoli hanya pada musim kemarau prokduksi garam di Madura dapat berhasil baik. Pemerintah sebagai pemegang monopoli berperan sebagai dinamisator dalam produksi hal itu tampak ketika terjadi krisis garam tahun 1859, sehingga pemerintah berusaha merangsang petani garam dengan menaikan harga garam dari 3,50 golden menjadi 10 golden. Akibatnya terjadi over produksi. Untuk mengatasinya pemerintah menutup ladang-ladang garam di Sampang dan Pamekasan pada tahun 1868 dan Sumeneppada tahun berikutya.

Penutupan ladang-ladang itu dibuka kembali pada tahun 1870 untuk Sumenep dan 1876 untuk Sampang dengan ketentuan produksi maksimal 24.000 koyang dan 7250 koyang. Untuk Pamekasan pembukaan ditunda karena ada kesulitan trasportasi.

Adanya kebijakan pemerintah kolonial tentang monopoli garam maka menimbulkan reaksi baik dari pembuat garam atau kelompok lain yang berpihak kepadanya seperti dilakukan oleh sarikat Islam lokal Madura. Organisasi SI mampu menggerakkan rakyat dengan maksud untuk membela kepentingan para pembuat garam dan pekerja garam. Gerakan SI belum pernah berhasil karena tempat tinggal orang-orang madura terpencar-pencar dalam tanean lanjang (halaman panjang) dan langkanya tanah pertanian yang subur, yang memungkinkan para petani berkumpul melalui sistem pengairan komunal yang ada.

Reaksi sebelum lahurnya SI lebih bersifat spontan dan bermotif ekonomi daripada politik. Reaksi muncul dari perorangan tanpa kordinasi dari pihak luar. Sebagai contoh reaksi itu berupa pembakaran gudang-gudang garam, yang dalam hal ini terdapat pihak-pihak yang diuntungkan, yaitu orang-orang yang bisa menjual bambu dan welit untuk membangun kembali gudang garam yang tebakar. Kejadian semacam itu merupakan tindakan balas

\footnotetext{
16 Jaar Verslag, hlm . 4-5.
} 
dendam dari petani garam, tetapi dalam pengusutanya sulit dibuktikan. ${ }^{17}$ Selain itu ada juga peristiwa yang berkaitan dengan pembuatan garam, yaitu pembuatan garam secara ilegal, kejahatan lain adalah pencurian garam oleh petani-petani garam, dan ada pula petani garam yang tidak mau menyerahkan garamnya kepada pemerintah.

Beberapa hal itu dapat dipandang sebagai reaksi terhadap peraturan monopoli yang sedang berlaku. Namun berbeda menurut apa yang dilaporkan oleh residen Surabaya ataupun asisten resisden Sumenep, bahwa adanya berbagai kejadian itu dilaporkan sebagai akibat dari upah atau harga garam yang dibayarkan kepada petani garam terlalu kecil. ${ }^{18}$

Tuntutan tentang kenaikan harga garam itu dilakukan karena adanya aturan-aturan dari pemerintah yang memberatkan petani garam. Peraturan itu antara lain : 1. perbaikan tambak garam 2. pembersihan kotoran yang perlu biyaya besar, 3. kecurangan dalam penimbanganoleh para pekerja pemerintah. Semua itu merugikan para pembuat garam.

Para pembuat garam melawan dengan cara 1. Tidak mengindahkan peraturan 2. Mengadakan pemogokan cara-cara itu tidak menyelesaikan masalah karena produksi garam yang buruk tidak akan diterima pemerintah. Setelah musim hujan datang maka garamnya larut dalam air. ${ }^{19}$

Adanya kesulitan yang dihadapi pembuat garam maka SI tampil sebagai mediator untuk menyamapaikan tuntutan kepada pemerintah. Ketika persoalan harga garam muncul sebagai masalah politik maka protes untuk menuntut kenaikan harga garam semakin banyak dukunganya pertemuan pertemuan selain diadakan Duko, juga dilaksanakan di Sampang pada 5 desember 1918 yang dihadiri oleh orang-orang dari 23 desa yang terdiri dari 448 pemilik tambak garam dan para pekerja yang mewakili 15.000 suara. Pertemuan serupa diadakan di Sumenep tanggal 6 Desember 1918 yang dihadiri oleh 357 orang dari 29 desa dan mewakili 25.000 suara. Dua hari kemudian ada lagi pertemuan di Pamekasan dengan peserta 325 orang dari 33 desa yang mewakili 20.000 suara.

Oleh karena pertemuan-pertemuan itu dilaksanakan dengan tertip maka pemerintah menanggapi dengan cara membentuk komisi yang terdiri dari 7 orang yaitu 4 orang Belanda dan 3 orang peribumi. Komisi ini diketuai oleh direktur departemen urusan garam. Salah satu dari ketiga orang itu adalah Haji Syadjili yang saat itu menjadi ketua SI di Madura, yang dalam komisi itu bertidak mewakili para pemilik ladang garam. Sedangkan 2 orang lainya mewakili pekerja dan dewan. ${ }^{20}$

Mengenai tuntutan kenaikan harga garam melalui sebuah komisi itu dipandang tidak efektif oleh para anggota SI karena didominasi oleh orang belanda. Pada tahun 1919 Haji Syadjili dikritik oleh Sosrodanukusumo, anggota SI cabang Sampang.

\footnotetext{
${ }^{17}$ P.H Van Der Kemp, Op. Cit., hlm. 280.

${ }^{18}$ Ibid, hlm. 298.

${ }^{19}$ Van Braam, Op. Cit., hlm. 103.

${ }^{20}$ Kuntowijoyo “Agama Islam dan Politik ....."Huubde Jonge (ed), hlm. 69.
} 
Haji Syadjili mendapat kritikan yang berbunyi : “ Bahwa ia telah gagal memperjuangkan para produsen gara”. Sementara itu keputusan tentang kenaikan harga garam belom ada kepastian. Sehingga hal itu menjadi salah satu penyebab SI merosot pada tahun 1920.24) ${ }^{21}$

\section{E. Kesimpulan}

Pelaksanaan monopoli garam di Madura pada awal abad ke 20, mengakibatkan timbulnya reaksi-reaksi dari para pembuat garam ataupun pihak-pihak yang berkepentingan seperti SI lokal di Madura.

Reaksi yang muncul sebelum lahirnya SI lebih bermitifkan ekonomi dari pada politik. Reaksi itu bersifat spontan dan tanpa adanya suatu usaha yang menggerakkannya, seperti halnya gerakan-gerakan sosial yang terjadi diberbagai tempat di Jawa, dimana pemimpin agama seperti Haji dan Kyai amat penting.

Setelah lahirnya SI, organisasi itu mampu memobolisasi rakyat dengan maksud antar lain untuk membela kepentingan para pembuat garam dan pekerja garam. Sekalipun gerakannya hanya bersifat pertemuan-prtemuan untuk menyampaikan tuntutannya tetapi pada masa sebelumnya hampir belum pernah berhasil. Hal itu disebabkan oleh karena tempat tinggal orang-orang Madura berpencar-pencar dalam tanean lanjang( halaman panjang) dan langkanya tanah pertanian yang subur yang memungkinkan para petani berkumpul melalui sistem pengairan komunal yang ada.

Kebanyakan gerakan sosial sebelum SI lahir adalah dilakukan oleh perorangan tanpa adanya koordinasi dari pihak luar, yaitu berupa pembakaran gudang-gudang garam. Perusuhperusuh itu dapat penghasilan dari penjualan bambu dan welit untuk membangun lagi gudang yang terbakar. Pembakaran gudang garam dapat dipandang sebagai reaksi terhadap peraturan monopoli garam yang berlaku. Selain itu para pekerja garam melakukan pemogokan dan para petani garam tidak bersedia menyerahkan garamnya pada pemerintah kolonial Belanda.

\section{DAFTAR PUSTAKA}

Cribb, Robert, The Late Colonial State in Indonesia Political and Economic Founation of Netherlands Indies 1880-1942 (Leiden: KITLV Press, 1994).

Ensiklopedia Nasional Indonesia (Jakarta:P.T.Cipta Adi Pustaka,1990)

Hastings Cham Berlin, The Theory of Monopolitic Competition, (London : Oxford University Press, 1956)

Huub de Jonge (ed). “Agama Islam dan Politik .....” Huubde Jonge (ed), Jaarverslag van de Dienstder zoutverpakking 1910-1911(Batavia: Landstrukerij 1912), "De Zoutregie” Koloniale Studien 1916-1917.

Mudji Hartono, “Migrasi Orang-Orang Madura ke Ujung Timur Jawa Timur”, Historia edisi

2011. Parwoto, “Monopoli Garam di Madura 1915-1920”, Tesis UGM 1996.

\footnotetext{
${ }^{21}$ Ibid., hlm. 70 .
} 
Kuntowijoyo, Social Change in An Agraria Society Madura: 1850-1940, (PhD.

Thesis Colombia University Press, 1972).

Sartono Kantodirjo, "Agrarian Redicalism in Java:Cultur and Politic's in Indonesia, (Ithaca:Cornell University Press 1972).

Scrieke, Indonesian Sosiological Studies, (Bandung: Sumur Bandung, 1960).

Tjdschrift Voor Nijverheid en landbour in Nederlandsch Indie, (Batavia: W. Ogelvia, 1863).

Verslag Van Den Zoutaanmak Op Madura, Over het jaar 1916-

1922, (Batavia: Landdrukerij, 1922).

Wertheim, Indonesia Society in Transition, (The Hague:W. Van Hoeve ltd, 1959). 